\title{
Rashtriya Madhyamik Shiksha Abhiyan in Punjab: Problems and Suggestions
}

\section{Shikha Sharma}

Department of Education, Punjab University, Chandigarh, India

Corresponding author: shikha.waka.7@gmail.com

Received: 24-04-2021

Revised: 19-07-2021

Accepted: 10-08-2021

\begin{abstract}
Rashtriya Madhyamik Shiksha Abhiyan (RMSA) is a scheme sponsored by central government of India in order to provide quality and secondary education. The scheme was launched by Government of India in 2009. The Scheme mainly aims at enhancing access to Secondary education and to improve its quality. It aims to augment the enrolment rate to $90 \%$ at secondary and $75 \%$ at the higher secondary stage, by providing a secondary school within reasonable distance of every home. The Scheme also focuses on removing barriers of gender, socio-economic and disability in order to provide universal access to secondary education in all secondary educational institutions. The present study intends to examine the problems and issues of RMSA in Punjab. In the present study, various guidelines of Rashtriya Madhyamik Shiksha Abhiyan (RMSA) has been studied to know the status of the scheme and how far it has been successfully implemented secondary schools in the state of Punjab. It has been found that many infrastructure facilities were not available for both students and teachers in the secondary schools of Punjab. The scheme aims to provide value education to the children belonging to rural areas by setting up of Model Schools as a standard of excellence at block level at the rate of one school per block. The objectives of the scheme are: (1) To have at least one senior secondary school of good quality in every block. (2) To have a progressive role for increasing quality of secondary education. (3) To suggest new innovative in curriculum and teaching process. (4) To be a model in infrastructure, curriculum, evaluation, and school governance.
\end{abstract}

Keywords: Rashtriya Madhyamik Shiksha Abhiyan (RMSA), phases of secondary education, problems and suggestions, curriculum

Secondary education covers two phases on the International Standard Classification of Education scale. Level 2 or lower secondary education (less common junior secondary education) is considered the second and final phase of basic education, and level 3 (upper) secondary education is the stage before tertiary education. Every country aims to provide basic education, but the systems and terminology remain unique to them. Secondary education typically takes place after six years of primary education and is followed by higher education, vocational education or employment. Like primary education, in most countries secondary education is compulsory, at least until the age of 16 .
Children typically enter the lower secondary phase around age 11. Compulsory education sometimes extends to age 19. Since 1989, education has been seen as a basic human right for a child; Article 28, of the Convention on the Rights of the Child states that primary education should be free and compulsory while different forms of secondary education, including general and vocational education, should be available and accessible to

How to cite this article: Sharma, S. (2021). Rashtriya Madhyamik Shiksha Abhiyan in Punjab: Problems and Suggestions. Educational Quest: An Int. J. Edu. Appl. Soc. Sci., 12(02): 131-135.

Source of Support: None; Conflict of Interest: None 
every child. The terminology has proved difficult, and there was no universal definition before ISCED divided the period between primary education and university into junior secondary education and upper secondary education. In classical and medieval times secondary education was provided by the church for the sons of nobility and to boys preparing for universities and the priesthood. As trade required navigational and scientific skills the church reluctantly expanded the curriculum and widened the intake. With the Reformation the state wrestled the control of learning from the church, and with Comenius and John Locke education changed from being repetition of Latin text to building up knowledge in the child. Education was for the few. Up to the middle of the $19^{\text {th }}$ century, secondary schools were organised to satisfy the needs of different social classes with the labouring classes getting 4 years, the merchant class 5 years and the elite getting 7 years. The rights to a secondary education were codified after 1945, and countries are still working to achieve the goal of mandatory and free secondary education for all youth under 19.

\section{Existing Status of Universalization of Secondary Education in Punjab in Relation to UEE}

In India, the foundation of modern education system was laid down by British rulers. In Assam also, western type of education began from preindependence era. The first secondary school of the state established in Guwahati during British period and this school is now known as 'Cotton Collegiate School'. After independence, the government of Assam adopted different schemes in collaboration with Central Government for the quick promotion of secondary education in the state. The state government of Assam like other states of the country has initiated a number of programmes for development of education.

\section{Problems}

Infrastructure facilities related issues: In Punjab, secondary education/schools have suffered from the lack of basic infrastructural facilities like lack of class rooms, table, chair, supply of electricity, drinking water facility; toilets etc. which are to be present in every secondary school for creation of conducive learning environment. Most of the secondary schools in the state are being run without minimum facilities i.e. inadequate facilities of building, laboratory, library, playground, inadequate lavatory system, separate toilet for girls, hostel facility for students, lack of pure drinking water facility, and lack of running water all the time in school and other equipments necessary for a good secondary school. Most of the secondary schools do not have separate computer room, separate staff room, principal's room, common room for students, auditorium or conference hall. There are not adequate numbers of instructional materials in the classroom, no proper seating arrangements for students with disabilities in most of the government secondary schools.

Curriculum related issues: Curricular structure and course offerings are the necessary condition for quality secondary education. Contemporary instructional processes and practices in secondary schools are characterized largely by lectures where students are passive listeners. Most importantly, they miss out on 'learning to know' or learning to learn through the present instructional process of the school. The curriculum is theory dominated. According to the academic specialists and experts in educational field, at secondary level should be diversified, useful and productive to students. Equal weight age should be given to theory and practice, but the existing pattern of curriculum is not relevant to suit the diverse needs, demands and talents of secondary students and thus fails to enable our students to face the challenges of life in modern society.

Teacher related issues: Teachers are integral part of the education system and it is on them that the responsibility of quality of education mainly rests. At present, the prescribed norm for teachers in secondary schools in Punjab is Bachelor's degree along with training which is also known as Bachelor of Education that imparts necessary pedagogical skills to impart education.

Teaching-learning process related issues: In most of the secondary schools of the state, teaching-learning process in the classroom is mainly dominated by lecture and traditional methods. There is a lack of interactive and participative learning methods at secondary level which makes the students passive learner. In most of the schools there is no provision 
of remedial teaching for slow learner and also no provision of enrichment materials activities for fast learner.

Teaching-aids related issues: Teaching-aids like blackboard, chalk, duster etc. are available in most of the secondary schools but there is a lack of modern devices such as projector, computer etc. and thus modern classroom communication devices are negligible in secondary schools. Teachers of the schools also do not show interest in using teaching aids properly in their teaching and there is a lack of interest and efficiency in the teachers to prepare teaching aids according to the need of the classroom presentation.

Library related issues: In Punjab, most of the secondary schools lack provision of good library building, lack of qualified librarian and lack of sufficient number of books. In some schools, a separate room is used as a library, but there is no adequate number of furniture, bookshelf, almirah etc. for keeping books systematically. Even students of secondary education are not encouraged to use library regularly and effectively for their academic benefit in the schools.

Evaluation/examination related issues: The process of evaluating the students' knowledge and performance is largely dominated by written examination and emphasis is given on development of rote-learning which is not supported by psychological principles of learning. Besides, there is no provision of self- evaluation of the students in the teaching leaning process in the schools. Regarding monitoring and school based supervision process at secondary schools, it can be said that there is no regular supervision of teacher's diary and inspection of class work, achievements, integrity and honesty in doing their duties.

Time-table related issues: In preparing time-table of the schools, maximum time is kept for conducting the classes of core-subjects. In most of the secondary schools of Punjab adequate time is not fixed in the school routine or time table for conducting cocurricular activities, for using library by students and teachers, project work and community work for students which are essential part of the educational programme of school education.

School management related issues: In most of the government schools heads/principals are less effective in using their leadership skills for motivating teaching and non-teaching staff to do their duties with competency and in maintaining discipline in school environment. In secondary schools principal/ head is to play the role of manager, guide and supervisor but due to the skills and interest most of the heads of the schools become failure to get proper support, co-operation and suggestions from teachers, members of school managing committee, parents and community members regarding the problems and developmental issues of the schools.

School guidance related issues: There is no provision of educational and vocational guidance for secondary school students. Even teachers of the schools lack adequate knowledge in this regard to provide necessary academic and vocational guidance to students and therefore unable to deal effectively the secondary students' academic, emotional and personal problems. Academic and vocational guidance and counselling is very important for secondary students but in the state of Punjab there is no Government and action programme for implementation of school guidance service in the schools.

Health care related issues: In Punjab, the provision of health care facility is not satisfactory in schools at both primary and secondary level. In most of the schools, there is no provision of regular health check-up of students, shortage of ambulance, no provision of physical education, no hygienic practices in school premises make the schools incapable for all round development of students.

Community participation and support related issues: Community participation and support in secondary school activities is essential as it helps to generate resources as well as good reputation of the school. But in most of the secondary schools there is no provision of regular interaction with parents of the students, no local NGOs, social workers, experienced and skilled persons are invited to discuss the issues related to school's progress and development in respect of society's expectations.

Transport and communication related issue: Most of the secondary schools located in remote and hilly areas are suffered from the problem of transport and communication related facility. There is no provision of providing school bus or other vehicle for carrying students who are coming from distant places. Many 
places of Punjab are flood affected and especially in rainy season students have to face the problem in continuing their schools for lack of good transport and communication facility.

\section{Suggestions}

1. There is need to enhance the gross enrolment ratios across secondary and higher education in the state with regard to gender and SCs and STs. The major flagship programmes namely Rashtriya Madhyamik Shiksha Abhiyan at secondary level and Rashtriya Uchatar Shksha Abhiyan at higher education level should adopt the successful enrolment drive strategies that are being implemented under Sarva Shikhsha Abhiyan across the state.

2. Achieving better transition rates from lower to higher stages of education and better completion ratio across higher secondary stage are some of the major issues that need to be tackled in an effective manner so as to increase the attainment of Dalits literacy rate in the state. It will go long way in sustaining the Dalits improvement in the growth process. Once the literacy rate of Dalits is improved, it will help them to utilize better economic opportunities and enhance their capabilities, there-by leading to socioeconomic empowerment.

3. The growth rate in number of teachers across districts was quite lower than the increase in the secondary enrolment across districts. Therefore RMSA should drive its attention toward these districts for the purpose of maintaining the ideal PTR.

5. The Worker's Participation Rates of females in the state across secondary and higher education is very lower when compared to the male's WPR. Further the WPR of female Dalits is dismal across these levels. Providing mere reservation in jobs has not yielded better results. Therefore Government should start specific job opportunities only to these sections of the population in order to ensure better inclusion of the disadvantaged section

6. The share of expenditure incurred on secondary education to that of the social service expenditure is quite lower in the state. In the context of universalization of secondary education in the state, there is greater need to increase the allocation of secondary education substantially to at least 35 per cent of the total educational expenditure of the state. Further RMSA programme being the major flagship programme for universalizing secondary education in the country forms only miniscule percentage of state's secondary education budget. Its share in the state's secondary education budget needs to be increased considerably in the context of universalizing secondary education. This should be addressed on a priority concern.

7. For bettering the inclusive growth process across higher education, Rashtriya Uchatar Shiksha Abhiyan at its initial stage should divert its funds towards addressing and resolving the access and equity issues that lead to upliftment of marginalized and socially deprived groups through its various proposed equity interventions in a pro-active manner. And in the later stage, it should focus on improving the quality aspect for strengthening the overall higher education system across the country.

8. A proper and inclusive database for secondary and higher education is the need of the hour. The study found some limitations in the database on secondary and higher education in the country as the enrolment data for OBCs and minorities were not included in the database. An inclusive database would be much helpful in undertaking ground level research in the areas of secondary and higher education. It would be beneficial in driving the higher education tot he path of inclusive Growth.

9. Finally the State should adopt the Four " $\mathrm{A}$ " framework of the UN Special Rapport on Right to Education by linking it with the Inclusive Growth strategy suggested by Chief Economist Ifzal Ali in a pro-active and synergized manner at each stage of education for bettering the inclusive growth process in education sector of the state. 


\section{CONCLUSION}

All movement in international level, a lot of changes have been taking place in India also and various policies and programmes to improve the access, participation and quality of elementary level have been introduced and implemented. The demand for universal secondary education in the country is coming largely due to enhanced literacy among parents, greater success of universal primary and upper primary education and growing awareness about value of education among people. Now in Assam like other states of India with the success in elementary education due to Sarva Shiksha Abhiyan, a large number of students have knocked the doors of secondary education. Therefore, universalisation of secondary education with quality in our state is the need of the hour and the cost of ignoring this issue of secondary education will be much heavier for the state than responding to the needs. Without the expansion and development of secondary education and its quality, overall development of the education system of a state/ country is not possible. Thus recognizing the role and importance of secondary education for all, it has been rightly said that twentieth century was the century of developing primary education whereas the twenty-first century is going to be the century of developing secondary education for all.

\section{REFERENCES}

Bandhopdhyay, M. 2010. Present Status of Infrastructure Facilities in Schools in India: National and State Level Perspective. Retrieved from http://www.dise.in/

Iflah S. 2019. Rashtriya Madhyamik Shiksha Abhiyhan in Jammu and Kashmir: Problems and Suggestion. J. Adv. Scholarly Res. Allied Edu., 16(1): 230-232.

Jayanta, D. 2015. Universalisation of Secondary Education in Assam: Problems and strategies. Int. J. Res. Eco. Soc. Sci., 5(8): 52-62.

Stanzin, N. 2017. Impact of Rashtriya Madhyamik Shiksha Abhiyan (RMSA) on Secondary Education in Kargil District of Jammu and Kashmir State. Int. J. Res., 4(13): 2348-6848.

Kalyani. 2011. Use of modern teachings aids in classrooms in India. Date: 01-April-2017. Retrieved from https://www. indiastudychannel.com.

https://shodhganga.inflibnet.ac.in/

https://steemit.comindian

http://mhrd.gov.in 
